\title{
ADULT MATHEMATICAL COMPETENCE IN THE CONTEXT OF SUSTAINABLE DEVELOPMENT: CASE OF BALTIC STATES
}

\begin{abstract}
Ilze BALODE, Faculty of Economics and Management, Ventspils University College, 101a Inženieru Street, LV-3601, Ventspils, Latvia, ilze.balode@venta.lv (corresponding author)

Anna VINTERE, Faculty of Information Technologies, Latvia University of Agriculture, 2 Liela Street, LV-3001, Jelgava, Latvia, anna.vintere@1lu.lv

Daiva RIMKUVIENÉ, Centre of Mathematics, Physics and Information Technology, Aleksandras Stulginskis University, 10 Universiteto Street, Akademija, Kaunas region, LT-53361, Lithuania, daiva.rimkuviene@asu.lt

Eve ARUVEE, Institute of Technology, Estonian University of Life Science, 56/1 Fr. R. Kreutzwaldi Street, Tartu 51014, Estonia, eve.aruvee@emu.ee

Mathematical competence is one of the eight basic key competencies which are defined by EU Directives. Mathematical competence includes the skills of applying basic processes and principles of mathematics in everyday contexts. The aim of current research is to identify the role of adult mathematics education and mathematical competence in sustainable development in case of Baltic States. We are continuing the investigations that began in the Nordplus research project "Cooperation to strengthen the citizens' math skills in the context of sustainable development and welfare". The main objective of the research is to highlight the role of mathematics in a lifelong context. We separate two aspects of mathematics role in sustainable development. The first considers mathematics as a tool in processional work, the second considers the role of mathematical competence in the development of person's intelligence and personality. Both aspects are widely discussed in the scientific literature and in the programmatic documents of United Nations, United Nations Educational Scientific and Cultural Organization, Organisation for Economic Cooperation and Development. Through combining insights of theoretical goals of leading international institutions and actual survey data we can show the value of mathematical competence in adults in the Baltic States.
\end{abstract}

Keywords: employees, employers, mathematical competence, sustainable development

\section{INTRODUCTION}

The present paper aims to discuss contemporary theory on sustainable development, mathematical competence and show these alongside actual survey data from the Baltic States. In this paper we apply the concept of sustainable development defined as "... development that meets the needs of the present without compromising the ability of future generations to meet their own needs." (UNESCO, 1987)

Sustainable development is a complex issue that many international agencies are working on, including the UN's implementation of the Agenda for Sustainable Development (UN, 2016), which addresses important global challenges for the next fifteen years, and includes 17 goals that are crucial to sustainable development and covers economic, social and environmental development.

These 17 goals have 169 targets (UN, 2015) and they heavily focus on human rights of all people and gender equality. The UN understands the importance of education therefore the goal (the proposed Sustainable Development Goal (SGD) 4) that is the most applicable to the issue looked at in this paper is this :"'”Ensure inclusive and equitable quality education and promote lifelong learning opportunities for all" (SGD4) and its corresponding targets." (UN, 2016) The data shown later in this paper show how mathematical education for adults impacts their work prospects and it could be assumed that all people in the Baltic States have access to various forms of education. Education is the key to sustainable development because it gives people a vision of future that focuses on equity, economy and ecology in all communities (Tillbury, Wortman 2004) and these are goals that should be important worldwide.

The OECD framework defines four types of "capital": natural capital, economic capital, human capital and social capital. (OECD, 2017b) One aspect of human capital is education that UNESCO (2017) sees as a ".. public good, a global common good .." and this shows that large international policy institutions see the importance of education in development. In 2012 UNESCO added a fifth pillar of education - learning to transform oneself and society to the four existing education pillars of learning to know, to do, to live together and to be (UNESCO, 2012).

Copyright (C) 2017 The Authors. Published by Aleksandras Stulginskis University. This is an open-access article distributed under the terms of the Creative Commons Attribution License (CC-BY 4.0), which permits unrestricted use, distribution, and reproduction in any medium, provided the original author and source are credited. 
In education mathematical knowledge plays a big role. The EU Recommendation on Key Competences for Lifelong Learning defines that: "Mathematical competence is the ability to develop and apply mathematical thinking in order to solve a range of problems in everyday situations.[...] An individual should be able to reason mathematically, understand mathematical proof and communicate in mathematical language, and to use appropriate aids. A positive attitude in mathematics is based on the respect of truth and willingness to look for reasons and to assess their validity." (EU, 2006)

A survey of people of the Baltic states about citizen's math skills was carried out during the Nordplus project "Cooperation to strengthen the citizens' math skills in the context of sustainable development and welfare".

In this paper we aim to give an insight into survey questions and the respondents' answers in a systematized, analyzed and interpreted way. The aim of the research is to identify the role of mathematics in the sustainable development in the lifelong learning context. We separate two aspects of mathematics role in sustainable development. The first considers mathematics as a tool in professional work, the second considers the role of mathematical competence in the development of person's intelligence and personality.

\section{RESEARCH METHODS}

The research is based on analysing and evaluating scientific literature and documents of European Union (EU), Organisation for Economic Cooperation and Development (OECD), United Nations (UN), United Nations Educational Scientific and Cultural Organization (UNESCO), World Economic Forum (WEF). The econometric calculations are taken from the Statistical Office of the European Communities and part of the European Commission (EUROSTAT) and OECD.

We utilize the results of the Nordplus project "Cooperation to strengthen the citizens' math skills in the context of sustainable development and welfare" which were obtained during the survey of the inhabitants of the Baltic States: Estonia, Latvia and Lithuania in 2014. The basic issues of the survey emphasized the role of mathematics in everyday life and the significance of mathematical knowledge in the labour market, and the respondent's professional career. Some aspects of survey touched upon the evalution of respondent's attitude towards lifelong learning, personality development, the role of mathematical knowledge in general and in particular. The research is based on fully-completed 878 respondents' answers provided during the survey. 649 respondents' completed employee questionnaire and 229 respondents filled out the employers' questionnaire. (For detailed survey data see: Vintere, A., Balode, I., Čerņajeva, S., Rimkuviene, D., Aruvee, E., Ideon, E. 2014. Transnational Comparative Study on the Math Educational Needs in Baltic States).

\section{RESEARCH RESULTS AND DISCUSSION}

The Technical Report of the Survey of Adult Skills (PIAAC) defines numerate behaviour as “...behavior founded on the activation of several enabling factors and processes: mathematical; knowledge and conceptual understanding; adaptive reasoning and mathematical problem-solving skills; literacy skills; beliefs and attitudes; numeracy-related practices and experience; context/world knowledge." (OECD, 2016c)

34 countries/economies participated in the last PIAAC (The Propgramme for the International Assessment of Adult Competencies) survey including Estonia and Lithuania; Latvia did not take part in this survey. In Estonia and Lithuania the numeracy skills (273 and 267, respectively) are above the average level of OECD countries, which is 263 (mean score). In Estonia and Lithuania gender differences in numeracy skills are small (OECD, 2016a).

In this paper we have chosen to separate two aspects of the role of mathematics in sustainable development into two parts: mathematical competence in the development of the person's intelligence and personality and as a tool in work environment.

Worldwide literature discusses the person's intelligence and personality, its formation, development and progress; special emphasis is put on the role of mathematical education. Willy Servais (1957) pointed out that: "Amid the intellectual properties, which mathematics develops, most often are mentioned those referring to logical thinking, namely, it is ability to reason deductively, ability to abstract, generalize, classify, ability to think, analyze, criticize." Today's researchers agree with this statement, because mathematics is a unique construction of human thought and it has many connections to our daily world in both every day and advanced science. (Gustafsson, Mouwitz, 2004)

In World Economic Forum report "The Future of Jobs Employment" identified 10 top skills: Complex Problem Solving, Critical Thinking, Creativity, People Management, Coordinating with Others, Emotional Intelligence, Judgement and Decision Making, Service Orientation, Negotiation, Cognitive Flexibility (WEF, 2016a, 2016b). In our opinion these skills: Complex Problem Solving, Critical Thinking, Creativity, Decision Making, Cognitive Flexibility can be developed with help of mathematical education. From a professional point of view the mathematical skills can be considered as an absolutely necessary tool for fulfilling the tasks at job. Experts expect employment growth in the STEM fields and a significant decline in Office and Administrative roles. "Among tertiary-educated adults in OECD countries, an average of $25 \%$ have studied in STEM fields. However, there are big differences across countries, ranging from $20 \%$ or less in Costa Rica, Iceland and the Netherlands to 30\% or more in Austria, Estonia, Germany and Spain.” (OECD, 2017a)

The further data research is based on statistics of 27 European countries: Austria, Belgium, Bulgaria, Croatia, Czech Republic, Denmark, Estonia, Finland, France, Germany, Greece, Hungary, Ireland, Italy, Latvia, Lithuania, Luxembourg, Netherlands, Norway, Poland, Portugal, Romania, Slovak Republic, Slovenia, Spain, Sweden, United Kingdom.

The Database of OECD Programme for International Student Assessment (PISA) was chosen for this research. PISA is aimed at testing literacy in three competence fields: reading, mathematics, and science. The results of PISA 2015 (OECD 2016b) are used: mean score in mathematics; share of low achievers in mathematics (Below Level 2); share of top achievers in mathematics (Level 5 or 6). The highest numbers of low achievers in 2015 were in Bulgaria (42.1), 
Romania (39.9) and Greece (38.5), but the lowest in Estonia (11.2), Finland (13.6) and Denmark (13.6), accordingly, in Latvia (21.4) and Lithuania (25.4). The lowest numbers of top achievers in 2015 were in Romania (3.3), Greece (3.9) and Bulgaria (4.4), but the highest in Belgium (15.9), Netherlands (15.5) and Estonia (14.2), accordingly, in Latvia (5.2) and Lithuania (6.9).

The Database of EUROSTAT was also chosen. In this paper we used the welfare indicator "People at risk of poverty or social exclusion" of 27 European countries in 2015 by EUROSTAT. For briefness, we shall further use "people at risk" to indicate people at risk of poverty or social exclusion. EUROSTAT defines this as: "At risk-of-poverty are persons with an equivalised disposable income below the risk-of-poverty threshold, which is set at $60 \%$ of the national median equivalised disposable income (after social transfers)." (EUROSTAT, 2017a) The highest value for the indicator "people at risk" in 2015 were in Bulgaria (41.3), Romania (37.4) un Greece (35.7), but the lowest values for this indicator were found in Czech Republic (14), Norway (15) and Netherlands (16.4). In the Baltic states, the highest risk of poverty is in Latvia (30.9), followed by Lithuania (29.3) and Estonia (24.4).

There is negative correlation of (-0.77) between "people at risk" and "mean score in mathematics". Also between indicators between "people at risk" and "share of top achievers in mathematics" a negative correlation is shown (-0.75), whereas between the indicators "people at risk" and "share of low achievers in mathematics" a positive correlation (0.72) can be found. In previous research (Balode, Vintere 2014) about the same 27 European countries, where data from 2012 was used, the correlation coefficients were $(-0.72),(-0.67)$ and $(0.68)$. The correlation between these indicators has become closer in the three past years. One of the conclusions is that the lower the mathematical abilities of a society are the greater the risk of poverty and social exclusion in a society is for more people.

Returning to the Nordplus project research data, they prove that more than $60 \%$ of respondents confirm that mathematical knowledge influences their everyday life. The inhabitants of the Baltic States evaluated the role of mathematics for personality development and for professional skills. In all three Baltic States the respondents ranked similarly the statements justifying the mathematical competence role in sustainable development.

Respondents-employees recognize mathematical competence for personality development as more important than for professional skills. The statement "Mathematics develops thinking, helps to make a decision in a particular situation, find new ideas" obtained the first position in survey. The people surveyed, agree to this statement in full or partly, $97 \%$ in Estonia, 94\% in Latvia and $83 \%$ in Lithuania. The statement "Studying mathematics develops logical thinking, accuracy and concreteness of future specialists", accordingly, was mentioned as the second most significant. Of the people surveyed, 95\% in Estonia, 94\% in Latvia and 81\% in Lithuania agree in full or partly to this statement.

Respondents recognized mathematical skills for professional needs in the second place. The statement "A person, who understands mathematics, will easily master most jobs that require them" was allocated as most agreeable for professional needs. Of the people surveyed, $90 \%$ in Estonia, $82 \%$ in Latvia and 64\% in Lithuania agree in full or partly to this statement. As the next was mentioned the statement "Mathematical thinking helps to solve real world/ professional problems". Of the people surveyed, $88 \%$ in Estonia, 76\% in Latvia and 59\% in Lithuania agree in full or partly to this statement. The last but not least is the statement "People, who understand mathematics well, are highly assessed by employers". Of the people surveyed, $83 \%$ in Estonia, $60 \%$ in Latvia and $48 \%$ in Lithuania agree in full or partly to this statement.

The respondents-employers recognize mathematical competence similarly for personality development and professional placement. The statement "I appreciate people who understand mathematics well" showed the employers' attitude towards the significance of mathematical knowledge in the personality development. Of the people surveyed, 95\% in Estonia, 86\% in Latvia and $90 \%$ in Lithuania agree in full or partly to this statement. In the private sector $89 \%$, in state owned enterprises $96 \%$ and $93 \%$ in local government of people surveyed in all three Baltic states agree in full or partly to this statement. Very similarly was evaluated the statement "A person, who understands mathematics, will easily master most jobs that require thinking" which shows the significance of mathematical knowledge in professional development. Of the people surveyed, $98 \%$ in Estonia, $82 \%$ in Latvia and $87 \%$ in Lithuania agree in full or partly to this statement. In the private sector $87 \%$, in state owned enterprises $96 \%$ and $92 \%$ in local government of people surveyed agree in full or partly to this statement.

Mathematics competence is equally important in all aspects of sustainable development and employment prospects at the same time. "The STEM fields [...] are seen as especially important for fostering innovation and economic growth. On average across OECD countries employment rates for STEM fields graduates are $86 \%$, ranging from $90 \%$ or higher in the CzechRepublic, Germany, Iceland, Lithuania, the Netherlands, Sweden and Switzerland to below $80 \%$ in Greece and Turkey. Tertiary-educated adults with a degree in STEM benefit from higher employment rates than their peers with a qualification in arts and humanities, social sciences, journalism and information across all OECD countries except Estonia (three percentage-point difference)." (OECD, 2017a) It could be concluded that also people who have higher general mathematical competence have a better chance at employment than those who do not possess this skill.

\section{CONCLUSIONS}

Both the earlier Nordplus research and its continuation show empirical evidence of the importance of the OECD, UN, UNESCO, EU and WEF documents qouted here. The research shows that adult mathematical competence encourages continous education and makes it easier, thus support in a potential career change.

The research also shows that both employees and employers highly value mathematical competence both for personality and professional development. 
However, it also shows that the adult mathematical competence in the Baltic states needs further improvements via modern teaching methods.

\section{REFERENCES}

1. Balode, I., Vintere, A. 2015. Study on Mathematical Literacy in the Context of the Household Welfare. In Rural Environment. Education. Personality. (REEP). Proceedings of the International Scientific Conference (Latvia), pp. 387-394. Latvia University of Agriculture.

2. European Union. 2006. Recommendation of the European Parliament and of the Council of 18 December 2006 on key competences for lifelong learning (2006/962/EC). Official Journal of the European Union, L394, 30 December 2006, pp. 10-18. Available at http://eur-lex.europa.eu/legal-content/EN/TXT/?uri=celex:32006H0962 (Accessed on 14/11/2017).

3. EUROSTAT. 2017a. People at risk of poverty or social exclusion Available at http://ec.europa.eu/eurostat/web/products-datasets//t2020_50\&lang=en (Accessed on 15/11/2017).

4. EUROSTAT. 2017b. People at risk of poverty or social exclusion. Main tables. Available at http://ec.europa.eu/eurostat/web/income-and-living-conditions/data/main-tables (Accessed on 14/11/2017).

5. Gustafsson, L., Mouwitz, L. 2004. Adults and mathematics — a vital subject. Gothenburg, Sweden: National Center for Mathematics Education. Available at http://ncm.gu.se/media/ncm/rapporter/adult-en.pdf (Accessed on 14/11/2017).

6. OECD. 2016a. Skills Matter: Further Results from the Survey of Adult Skills, OECD Skills Studies, OECD Publishing, Paris. https://doi.org/10.1787/9789264258051-en

7. OECD. 2016b. PISA 2015 Results (Volume I): Excellence and Equity in Education, PISA, OECD Publishing, Paris. Available at (Accessed on 14/11/2017). https://doi.org/10.1787/9789264266490-en

8. OECD. 2016c. Technical Report of the Survey of Adult Skills (PIAAC) (2nd Edition). Available at https://www.oecd.org/skills/...PIAAC_Technical_Report_2nd_Edition_Full_Report.pdf (Accessed on 14/11/2017).

9. OECD. 2017a. Education at a Glance 2017: OECD Indicators, OECD Publishing, Paris. https://doi.org/10.1787/eag-2017-en

10. OECD. 2017b. Measuring Distance to the SDG Targets: an assessment of where OECD countries stand. Available at http://www.oecd.org/std/OECD-Measuring-Distance-to-SDG-Targets.pdf (Accessed on 14/11/2017).

11. Serve, V. 1957. Teaching mathematics in secondary schools. Mathematical Education, Vol. 1, pp. 22-32. [In Russian]

12. Tilbury, D., Wortman, D. 2004. Engaging People in Sustainability, Commission on Education and Communication, IUCN, Gland, Switzerland and Cambridge, UK.

13. UNESCO. 2012. Education for Sustainable Development. Available at http://unesdoc.unesco.org/images/0021/002163/216383e.pdf (Accessed on 14/11/2017).

14. UNESCO. 2017. Education for the Sustainable Development Goals: Learning Objectives http://unesdoc.unesco.org/images/0024/002474/247444e.pdf

15. United Nations. 1987. Report of the World Commission on Environment and Development "Our Common Future".

16. United Nations. 2015. Transforming our world: the 2030 Agenda for Sustainable Development. Resolution adopted by the General

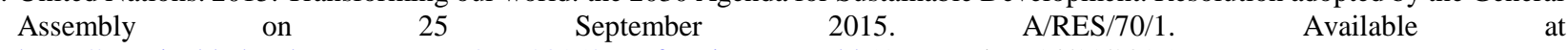
https://sustainabledevelopment.un.org/post2015/transformingourworld (Accessed on 14/11/2017).

17. United Nations. 2016. The Sustainable Development Goals Report 2016. New York. Available at http://www.un.org.lb/Library/Assets/The-Sustainable-Development-Goals-Report-2016-Global.pdf (Accessed on 14/11/2017).

18. Vintere, A., Balode, I., Čerņajeva, S., Rimkuviene, D., Aruvee, E., Ideon, E. 2014. Transnational Comparative Study on the Math Educational Needs in Baltic States.

19. World Economic Forum. 2016a. The Future of Jobs Employment, Skills and Workforce Strategy for the Fourth Industrial Revolutio. Global Challenge Insight Report. Available at http://www3.weforum.org/docs/WEF_Future_of_Jobs.pdf (Accessed on 14/11/2017).

20. World Economic Forum. 2016b. The 10 skills you need to trive in the Industrialial Revolution. Available at https://www.weforum.org/agenda/2016/01/the-10-skills-you-need-to-thrive-in-the-fourth-industrial-revolution/ (Accessed on $15 / 11 / 2017)$ 